\title{
Model Politic Student Doing Local Government Policy Advocacy In North Sumatera
}

\author{
Muhammad Arifin Nasution, Rudy Salam Sinaga \\ Faculty of Social and Political Sciences University Sumatera Utara, Doctoral Student of Social Science \\ University of Diponegoro \\ Medan, Semarang City-Indonesia \\ muhammadarifinnasution@gmail.com
}

\begin{abstract}
The decentralized system of the Indonesian government to give jobs to the region to carry out development in the area in response to the various regional development policy. Offend public policy perspective the role of government and stakeholders. The focus of the stakeholders in this research is student organizations. This study aims to investigate the model student political movement in advocating for policies in the autonomous region in the province of North Sumatera. The method of investigation used to answer research questions using a mixed methods design sequential exploratory through collaboration grounded theory approach and surveys. Data gathering using depth interview and survey techniques used to test the hypothesis that emerged from the research results at the earliest. The study population is groups of student movement organizations in the province of North Sumatra with a set of samples of the four groups of organizations active student movement at the University of Sumatera Utara. The findings of this study describe a group of student movement organizations in conducting policy advocacy stages tend stalled at the stage of political socialization in advocating policies and limitations in order to maximize the level of policy advocacy in the parliament lobby.
\end{abstract}

Keywords - political movement; student organizations; policy advocacy; the regional government.

\section{INTRODUCTION}

Student movement phenomenon in many states in the world have protested to state policy gave a sign that there was unresolved issues within the framework of the policy formulation process. Protests against the state policy is a usual phenomenon in a democratic country, [1] there are three things in a democratic country, namely: (1) competition in the fight and maintain power, (2) society participation, and (3) the existence of a guarantee civil rights and politics. The phenomenon protest against the policy of the state is part of a form of society participation to control the development of the country and also in protest of citizens as the elaboration of civil rights and political owned every citizen was protected and respected by the constitution of a democratic state.

To analyze the phenomenon of advocacy undertaken by the student organization in region, this study used policy advocacy theory proposed [2] as a community action to change the situation arising from the consequences of the policy. To be able to browse the model of advocacy undertaken by a student organization, This study also uses the theory of "Advocacy Coalition Framework" (ACF) by $[3,4,5]$ as a supporting theory. The second theory (Policy Advocacy and ACF) considered able to analyze the three things that will be investigated in this study: 1) the actor, 2) influence policies activity and 3) the policy that will be affected to find a model of a political movement of student organizations in influencing policy in the province of North Sumatra. Both theories used in democracy perspective moreover public policy perspective in modern democracies it is considered a wellestablished theory is used as a tool of analysis in this study and to strengthen of investigation method, this research was supported by descriptive quantitative method to test the qualitative findings were obtained.

A number of empirical work in several countries to investigate the role of the student movement in influencing state policy in the political approach and a social approach as some of them empirical study [6] on the campus of La Universidad Nacional Mayor San Marcos-Peru. Student political movement on the campus of Columbia University [ $\left.{ }^{7}\right]$, dissertation works [ ${ }^{8}$ ] in Poland and dissertation work $\left.{ }^{9}\right]$ in Iran and there are many more studies that can be traced.

In the context of Indonesia a number of empirical studies that investigate the student movement can be traced from the various works such as $\left[{ }^{10}\right]$ investigate the political attitudes of students in the two eras of leadership that era president B.J. President Habibie and Abdurrahman Wahid, The political dimension of the student movement in Bandar Lampung [11], The factors that cause social movements of 
students[12], Alliance of farmers and students in Yogyakarta and there are still other works[13].

Indonesia government system after the reform movement with analyze the regulation of Indonesia number 32 Year 2004 about Regional Government explain that Indonesia government system referring to the principle of decentralization and deconcentration. Decentralization principles that focus on the acceleration of development in the area and to pursue that, the concept of decentralization in Indonesia provides the authority for the autonomous regions to set up and administer governmental affairs in the region that includes the obligatory functions and affairs of choice. Except in foreign policy, defense, security, justice, monetary and national fiscal and religious which is the authority of the central government.

Departing from the analysis of the systems approach Indonesian government through decentralization principles that put the concentration of regional development carried out by the local governments through a variety of policies. When the policy assessed [14] as "anything a government chooses to do or not to do", so the policy important to note because it involves what is done and not done by government can be meaningfully spacious moreover, if a policy affects triggering attitude public protests. In the autonomous region context of North Sumatera Province, one of the public elements which active give attention on public policy at national and regional (local) are student activists group, this study aims to investigate the model of student political movement in advocating public policy in the province of North Sumatera

The object of research is focused on five student organizations located in North Sumatra Province, namely: 1). National Student Front or Front Mahasiswa Nasional, 2). Muslim Students Association or Himpunan Mahasiswa Islam, 3). Indonesian Muslim Student Action Union or Kesatuan Aksi Mahasiswa Muslim Indonesia, 4). Indonesian Christian Student Movement or Gerakan Mahasiswa Kristen Indonesia, 5). Indonesian National Student Movement or Gerakan Mahasiswa Nasional Indonesia, The whole object of this study took sample 5 student organizations in the University of Sumatera Utara. There are several reasons for setting 5 student organizations as the object of this study include the following 1) fifth student organization that became the object of research as active organization in policy advocacy in North Sumatra province, 2) It has branch offices in other universities nationally so that it can be said as a large organization 3) the fifth student organizations have different values of the ideology of the organization, 4) has alumnus who work in political institutions and political parties.

Selection of the five student organizations with take samples in the University of North Sumatra due to several considerations, namely: 1) University of Sumatera Utara as the popular University in North Sumatera Province, 2) Has the recruitment process student selection is tight and limited, 3) Majority of the students have high spirit learning with indication of the recruitment process and a rigorous selection limited, 4) University of Sumatera Utara is located in Medan city, and North Sumatra provincial government office domiciled in this city.

\section{RESEARCH METHODS}

The study used a combination of methods with Sequential Exploratory models. The first phase of the study used a qualitative method with a Grounded Theory approach then at a later stage using quantitative methods with a survey approach to corroborate the hypothesis of the results of qualitative methods. The qualitative data obtained through interviews, observation and documentation with data analysis using a model of Miles and Huberman [15],for the collection of quantitative data using a questionnaire with data analysis using descriptive statistical analysis. The informant research board is representative of five student organizations, namely 1) Himpunan Mahasiswa Islam (HMI) Commissariat in Faculty of Social and Political Sciences, University of Sumatera Utara. 2) Gerakan Mahasiswa Nasional Indonesia (GMNI) Commissariat in Faculty of Social and Political Sciences, University of Sumatera Utara. 3) Front Mahasiswa Nasional (FMN) Branch of the University of Sumatera Utara. 4) Kesatuan Aksi Mahasiswa Muslim Indonesia (KAMMI) Merah Putih University of Sumatera Utara. 5) Gerakan Mahasiswa Kristen Indonesia (GMKI) Commissariat in Faculty of Social and Political Sciences, University of Sumatera Utara. Sample of respondents was determined by accidental sampling with a sample size of 50 respondents were divided on each student organizations so that respondents from each student organizations set as many as 10 respondents. 


\section{POLITICAL MODEL STUDENT MOVEMENT POLICY ADVOCACY IN DOING IN NORTH SUMATERA}

Referring to the explanation oxford dictionary, advocacy is defined as public support for or recommendation of the cause or specific policies, profession or occupation of the legal advocate. while the understanding of policy according to oxford dictionary relating to the guiding principles of action. It can be concluded is a policy advocacy activities undertaken by the community to provide solutions to problems arising from a particular policy through the process and principles recognized by the state. Advocacy is not just a move in the court, but more than that can be reached through media advocacy and political institutions as stated [16] advocacy is not only a tool for public policy reform, but also can become a means of social and political transformation, due to its impact could be increased public participation, government transparency, accountability within the structure, and the policymaking process.

Policy advocacy at the level of applicative extremely varied and complex [17].Variation in the level of applicative and complexity in conducting policy advocacy can be due to several factors, such as the difficulty to realize the policy advocacy because it takes a long time [18]. In this research, policy advocacy theory used is as proposed [19] implemented by public policy advocacy for policy change.

Advocacy requires public participation to achieve effective policy, the activities of policy advocacy go hand in hand with the universal principles that apply in a democracy with so advocacy is a relevant method to influence policy in the modern democratic state. Policy advocacy aim to obtain effective policy [20], presenting an effective and responsive government $[21,22]$. At the level of applicative variety of shapes policy advocacy activities carried out in different ways and with different objectives.

Activities can not be ignored in policy advocacy process to gain public policies that benefit the public because of policy advocacy activities have an important role as alluded $\left[23,24,{ }^{25},{ }^{26}\right]$ to present to the public policies that favor the activity of advocacy development policy requires movement required for success as an effective impact on the objectives of policy advocacy. policy advocacy success is influenced by several factors, including the extent of support network is obtained actors advocate policies to make this happen through a coalition of support tissue formation becomes important to realize. On a theoretical level $[27,28,29]$ contribute to their theoretical approach related to coalition in policy advocacy activities with theoretical approaches of The Advocacy Coalition Framework (ACF). ACF emphasis attention on building a coalition based on confidence in the core policy, research activities and the formation of public opinion and demonstration. ACF used as concept models to investigate the process of formation of the coalition in policy advocacy activities conducted by a student organization in the province of North Sumatera.

Although public policy advocacy is not a new phenomenon at the level of applicative well as new studies on the empirical nevertheless all public policy continues to be produced and so long as it is also the study of policy advocacy is still a theme that is interesting and important to be investigated especially in cases where the change system in the country. From the search a number of empirical studies that have been found associated with the investigation of the policy advocacy process can be seen from a number of works $[30,31,32]$ and there are many other empirical studies.

The perspective of public policy studies look at two groups that appear to respond to a policy group that presser and interest groups. In the presser study group and interest groups in almost all democratic countries including Indonesia show policy advocacy activities performed by Non Government Organization (NGO). In democracy country, [33] Role of NonGovernment Organizations (NGO) providing policy advocacy training for interest groups, [34] NGOs have the capacity to undertake the development of social capital in society with different approaches. [35] NGO or more broadly in civil society can realize good governance Good Governance through policy analysis and policy advocacy.

In the scope of North Sumatra Province role of NGOs seem so evident in the policy advocacy NGO one of the elements that take an active role in policy advocacy is implementing student organizations. In North Sumatra there are also many elements of the student organization that organized formally in the form of a structured organization both locally and nationally. In connection with this study which focuses attention on five actors active student organizations protesting policies through policy advocacy activities research seen through observation and local mass media. Fifth organizations active students become actors in 
policy advocacy movement is : 1) HMI, 2) GMNI, 3) GMKI, 4) FMN, 5) KAMMI.

Information collected through interviews informants coming from the board five student organizations are known student organizations have the same profile on aspects of organizational structure and decision-making in internal organization, the difference between them lies in the ideological values of the organization. When traced deeper ideological differences inherent in the organization they have in common in terms of the aspect of high concern to the principles of justice especially in the context of the substance of public policy which adversely affects the public.

Table: Comparison of Structure and Value Ideology Student Organization

\begin{tabular}{|l|l|l|l|}
\hline $\begin{array}{c}\text { Organization } \\
\text { name }\end{array}$ & \multicolumn{1}{|c|}{ Organizational structure } & \multicolumn{1}{|c|}{ Decision-making } & \multicolumn{1}{|c|}{ value ideology } \\
\hline HMI & Decentralized organizations & Inclusive & $\begin{array}{l}\text { Nationalism Religion } \\
\text { (Islam) }\end{array}$ \\
\hline GMNI & Decentralized organizations & Inclusive & $\begin{array}{l}\text { Nationalism Marhenism } \\
\text { (Christian) }\end{array}$ \\
\hline GMKI & Decentralized organizations & Inclusive & Nationalism Democratic \\
\hline FMN & Decentralized organizations & Inclusive & $\begin{array}{l}\text { Nationalism Religion } \\
\text { (Islam) }\end{array}$ \\
\hline KAMMI & Decentralized organizations & Inclusive & \\
\hline
\end{tabular}

Source: Interviews and a review of the organization's internal rules

The majority of the background actors who are in the fifth individual student organizations are individuals who come from families with low economic level and being with reference to the survey data have led to the assumption of the individual actor's interest in five organizations due to simple and limited life experience makes them indifferent to relieve or pro-change issues to the public. More detailed survey results shown in the table below:

Table: Income Levels Student Parent

\begin{tabular}{|l|c|}
\hline \multicolumn{1}{|c|}{ Answer } & Percent \\
\hline Rp. 1.000.000.-2.000.000. & $28 \%$ \\
\hline Rp. 3.000.000.-4.000.000. & $50 \%$ \\
\hline Rp. 5.000.000.-6.000.000. & $14 \%$ \\
\hline Rp. 7.000.000.-15.000.000. & $4 \%$ \\
\hline Do not know & $4 \%$ \\
\hline
\end{tabular}

Progressive changes require social costs [36]. To realize a change requires several actors involved to make changes. Social change comes as a result of product policies and to influence policy made an approach known as policy advocacy. [37] Policy advocacy as an activity that deliberately created the public for a change in policy. From indepth interviews conducted on informants in 5 student organization known models in the student political movement advocating regional policy is conducted in stages 1) build collective perception, 2) management action, 3) demonstration, 4) build a coalition.

\section{A. Building a Collective Perception}

The entire student body is the object of research has organizational unit or division that specifically follow the development issues of concern among the people, both the issues related to national policy and regional policy. The issue that received high response from society characterized by the presence of high resistance in the public discourse be a strong indicator to be able to get into the internal agenda to be discussed student organization through internal discussions.

Another way the inclusion of an issue on the agenda is through the internal instructions or calls from their organizational structures higher as the organizational structure of the branch or center (big board). When the issue has gained 
ditataran internal organizations through discussion and gave birth to collective perceptions and issues later accomodated to be fought in the form of the measures agreed upon collectively as whether the issue of the problem will be discussed returning to public areas such broader cross-organization for support or can be directly to the step for improved management mechanisms of action.

In the process of discussion at the level internal organizational dynamics are so dynamic, dynamic thinking and dialectical process in order to rationalize the idea of the issues addressed showing shades of ideological work to give birth to the idea. Varian dialectic modifications appear to be present as a 'color' that emerge from the influence of the books he had read and thought a growing influence of the environment around. The dynamics of the dialectic ideas will move on the state of higher volume when the issue is brought to a wider area such as the issues discussed along with other student organizations. The high volume of the dynamics of the dialectic idea materialized as 'color' which prevalent as a form of explanation to the environmental discussion of issues related to the control problem. The positive aspect that is created on the state of discussions between organizations is the presence of shared learning through a dialectic approach of thought and style narrated.

\section{B. Action Management}

Collective perception that has formed on the stage of internal discussion or external discussion will be determined what measures will be taken through the stages of management action. Management action tendency discuss three things: 1) The form of action like what was done to address the issue of policy issues. 2) Which institutions that will be addressed, 3) When is the time for action policy advocacy carried out, 4) Where the point gather before running the policy advocacy, 5) Who (organizations) who participated in the advocacy 6) What is the target number of times that follow Advocacy, 7) Supplies advocacy actions and 8), When and where evaluation of advocacy activities will be discussed.

The tendency of the student organization at the fifth stage of the action does not equip management with the data-based action research or policy paper. This condition is caused due to the low level of knowledge to formulate researchbased data on the other hand although they recognizes the important aspects of the use of policy paper in policy advocacy activities. From the results of a survey of all respondents in five student organization known $42 \%$ of respondents never use the policy said, $4 \%$ of respondents answered very frequent use, and $48 \%$ said no and $6 \%$ never answered so never use the policy paper.

The percentage of answers is in line with findings from the interviews that reveal the lack of use policy paper on advocacy activities. Known throughout the student organizations use rationalization to explain the causes and solutions of a policy that is being advocated by the paper 'statement'. There are large differences in terms of posture systematic and scientific principles, between the paper statement with a policy paper. Thus respondents who answered never use the policy paper is still in the data category 'bias' because of an error in distinguishing policy paper and paper statement. Answer 'bias' is clarified later traced to the next question concerning the knowledge to make policy paper found the answer $10 \%$ so do not know, $64 \%$ do not know, $24 \%$ and $2 \%$ know very knowing. With this data reinforces the conclusion that to mngembil of five student organizations tend to never use the current policy paper to advocate policies due to confusion in preparing the policy paper.

Table: Knowledge To Develop Policy Paper and Usage Policy Paper On Advocacy Activities

\begin{tabular}{|l|c|l|c|}
\hline \multicolumn{2}{|c|}{ Knowledge To Develop Policy Paper } & \multicolumn{2}{c|}{ Usage Policy Paper On Advocacy Activities } \\
\hline \multicolumn{1}{|c|}{ Answer } & Percent & \multicolumn{1}{c|}{ Answer } & Percent \\
\hline Very often & $4 \%$ & Very Aware & $2 \%$ \\
\hline Ever & $42 \%$ & Knowing & $24 \%$ \\
\hline Never & $48 \%$ & Do not know & $64 \%$ \\
\hline Very Never & $6 \%$ & Very Not Knowing & $10 \%$ \\
\hline
\end{tabular}

Source: Survey 2016

\section{Demonstration}

Demonstrations tend to be the top choice for the whole organization to advocate policies in the form of protest and express their statement. Demonstrations as a practical way to do since demonstrations as a way that has been 
understood by a student organization to attract the attention of policy makers in a way took to the streets, make speeches in front of the political institutions concerned and how demonstration can draw the attention of the mass media, so it helps in giving influence public perception to a wider area.
Demonstrations at the level of applicative not always go according to what is expected by a student organization, the low response of policy makers in responding to the protests which they fought looks at perceptions of student organizations assess the responsiveness of the DPRD to the aspiration of only $6 \%$.

Table: Levels Responsiveness North Sumatera Provincial Assembly Members According to Respondents

\begin{tabular}{|l|c|}
\hline \multicolumn{1}{|c|}{ Answer } & Percent \\
\hline Responsive & $6 \%$ \\
\hline Unresponsive & $80 \%$ \\
\hline Very unresponsive & $14 \%$ \\
\hline
\end{tabular}

Source: Survey 2016

Parliament responsiveness can be played on two aspects namely 1) the aspect of responsiveness receive aspiration when there are demonstrations and 2) the aspect of responsiveness of the aspirations of the demonstration. The quality of these two aspects important to be considered by legislators and regulatory framework should also provide normative procedure that does not really take a long time for an aspiration which can fit into the policy agenda. This procedural process involves time and discussion in each stage so that it can be concluded to be pursued expect aspiration into the policy agenda is not enough just to do a demonstration or a demonstration repeatedly.

\section{Advocacy Coalition Movement of Student Organization}

Coalition along with other organizations to be a step that tends to be used by a student organization in protest of regional policy. The aim of the protest coalition of organizations is understood as the right way to expand the collective perception of protest against the policy and as an easier way to mobilize in protest activities. The survey conducted shows the percentage that underlie the creation of a coalition of organizations in protest activity policies with the result $80 \%$ of respondents said the coalition was formed due to the problems faced as a mutual problem, $16 \%$ of respondents stated for reasons of equality ideology and 4\% said the coalition was formed due to the need for the purpose of mobilizing mass. These results indicate the approach of ideology and purpose of mobilizing the masses have little role in the formation of the coalition, the coalition will be more easily realized when the issue at a policy conceived as a mutual problem.

Theory ACF pays great attention to the activity of advocacy coalitions in order to bring the influence of the strong power to shape perceptions of the actors policy makers and the public in order to stand on the same perception through rationality with a data-based research for the causes and solutions of a policy that is problematic. At the level of reality to the object of this study, a coalition of advocacy was formed consciously by any student organization but advocacy activities have weaknesses in implementation to give effect ditataran change the perception of policy makers due to the tendency of each activity policy advocacy by a student organization is weak in the use of databased research to be used as a basis to influence the perception of policy makers. The protest movement through demonstrations allow all to involve other organizations in the form of alliances movement. To realize the movement alliances in addressing a protest to the policies fifth student organizations assess coalition materialized movement on the background ideology of equality and equality of collective organization protested against the policy as shown in the survey below :

Table: Background Form Coalition

\begin{tabular}{|l|c|}
\hline \multicolumn{1}{|c|}{ answer } & Percent \\
\hline similarity ideology & $16 \%$ \\
\hline common perception of the problem & $80 \%$ \\
\hline The need for mass mobilization & $4 \%$ \\
\hline
\end{tabular}

Source: Survey 2016 
Coalition formed by bonding a conscious collective perception that can run concurrently with other similarities as example [38] ethnicity, [39] ideological model, $\left[{ }^{40}\right]$ specific purpose (of Land Rights). In each role performed by student activists in the political movement shows the processes and patterns that differ from one group against another, between one issue with other issues such as finding [ $\left.{ }^{41}\right]$ the model of ethnic political mobilization in Algeria, $\left.{ }^{42}\right]$ political culture and [43] alliance network model.

\section{CONCLUSION}

The research findings show a model student political advocacy movement to influence local policies embodied in four models, namely the approach phase 1) build collective perception, 2) management action, 3) demonstration, 4) build a coalition. The model of this stage has been a tradition of institutionalized among student organizations have long used this stage to influence public policy from one generation to the next, on the other hand their lack of knowledge in compiling the data-based research such as the policy paper and build networks in parliament makes it difficult to measure the effectiveness of policy advocacy that they have done.

\section{RECOMMENDATION}

To determine the size of an advocacy action can be effective only when the process is known to affect such advocacy can be traced in the development of political institutions concerned, to be able to measure the development of advocacy action will require the use of policy paper, lobby parliament and blow up the media. So that the relevant policy advocacy model to be applied to modern democratic country like Indonesia especially for the intellectual actors campus close to the research climate it is advisable to add the model policy advocacy into the following stages: 1 ) build collective perception, 2) management action, 3) granting policy paper to policy makers, 4) building advocacy coalitions, 5) lobby parliament, 6) blow-up media, 7) demonstration.

The lobby is well-established as a profession in a democracy and universities in the United States has put skill lobby within the university curriculum [44]. Implementation of advocacy model as suggested above can be implemented not in order to address the needs and circumstances, or may also be modified by cultural or religious approach for the autonomous regions which have a cultural identity and religious identity is so strong.

\section{ACKNOWLEDGMENTS}

This study still has limitations on broad populations and samples. Thanks to Government Studies at the University of Medan Area, Doctoral program in social sciences at University of Diponegoro, Department of Political Science University of Sumatera Utara, Thanks to student organizations within the university of Sumatera Utara; Kesatuan Aksi Mahasiswa Muslim Indonesia (KAMMI), Himpunan Mahasiswa Islam (HMI) Commissariat in Faculty of Social and Political Sciences, Front Mahasiswa Nasional (FMN) Branch of the University of Sumatera Utara, Gerakan Mahasiswa Nasional Indonesia (GMNI) Commissariat in Faculty of Social and Political Sciences, Gerakan Mahasiswa Kristen Indonesia (GMKI) Commissariat in Faculty of Social and Political Sciences.

\section{REFERENCES}

[1] Marijan, K. (2010). Sistem Politik Indonesia: Konsolidasi Demokrasi Pasca Orde Baru. Jakarta: Kencana Prenanda Media Group, pp. 83

[2] Gen, S., \& Wright, A. C. (2013). Policy Advocacy Organizations: A Framework Linking Theory and Practice. Journal of Policy Practice, 12(3), 165.http://ro.uow.edu.au/cgi/viewcontent.cgi?arti $\underline{\text { cle }=1897 \& \text { context }=\text { sspapers, }}$, access February 2 , 2017.

[3] Sabatier, P.A., and Jenkins-Smith, H. (eds.) (1993). Policy change and learning: an advocacy coalition approach. Boulder, CO: Westview.

[4] Sabatier, P. A., \& Jenkins-Smith, H. C. (1999). The advocacy coalition framework: An assessment. Boulder, CO: Westview Press. pp 142.

[5] Sabatier, Paul A. (1998). The advocacy coalition framework: revisions and relevance for Europe, Journal of European Public Policy, 5(1): 98-130

[ $\left.{ }^{6}\right]$ Haanstra, A. (2008). The Politics of Democracy: Student Political Engagement at La Universidad Nacional Mayor San Marcos, Lima, Peru. Thesis. Dalhousie University, Halifax, Nova Scotia.

[7] Slonecker, B. (2006). The Politics of Space: Student Communes, Political Counterculture, and The Columbia University Protest of 1968. Thesis. University of North Carolina.

$\left.{ }^{8}\right]$ Michael, E. (1996). Intellectuals in Search of A Social Movement; The Political and Strategic Choices of Kor. Dissertation. University of Connecticut.

[9] Matin-Asgari, A. (1993). A history of the Iranian student movement abroad: The Confederation of Iranian Students/National Union (1960-75). Dissertation. University of California. 
$\left.{ }^{10}\right]$ Hasibuan, M. U. S. (2010). Gerakan Politik Mahasiswa: Studi Kasus Polarisasi Gerakan Mahasiswa Pada Masa Pemerintahan B.J. Habibie dan Abdurrahman Wahid. Disertasi. Universitas Indonesia. http://www.lib.ui.ac.id/detail?id=132052\&lokasi =lokal\#horizontalTab2, access February 2, 2017.

$\left.{ }^{11}\right]$ Suwondo. (2002). Gerakan Mahasiswa Bandar Lampung: Tinjauan Dalam Dimensi Politik. Disertasi. Universitas Indonesia.

[12] Matulessy, A. (1997). Faktor-faktor Penyebab Gerakan Sosial Mahasiswa. Tesis. Universitas Gadjah Mada.

[13] Aminwara, R. (2004). Dinamika Gerakan Petani: Studi Tentang Aliansi Petani dan Mahasiswa Yogyakarta. Tesis. Universitas Gadjah Mada.

$\left[{ }^{14}\right]$ Dye, Thomas R. (1972) Understanding Public Policy. Englewood Cliffs: Prentice-Hall, pp. 2.

$\left.{ }^{15}\right]$ Miles, MB. \& Huberman, AM. (1994). Qualitative Data Analysis, (2nd edition). Thousand Oaks, CA: Sage Publications.

$\left.{ }^{16}\right]$ Espine-Villaluz, S., Reyes, M., \& Mapa, J. (2004). Manual Advokasi Kebijakan Strategis. Sweden: International IDEA, pp. 1.

$\left[{ }^{17}\right]$ Gen, S., \& Wright, A. C. (2013). Policy Advocacy Organizations: A Framework Linking Theory and Practice. Journal of Policy Practice, 12(3), 163.

[18] Sabatier, P. A., \& Jenkins-Smith, H. C. (1999). The advocacy coalition framework: An assessment. Boulder, CO: Westview Press

$\left[{ }^{19}\right]$ Gen, S., \& Wright, A. C. (2013). Policy Advocacy Organizations: A Framework Linking Theory and Practice. Journal of Policy Practice, 12(3), 165.

$\left[{ }^{20}\right]$ Kastens, B., and J. Newig. 2008. Will participation foster the successful implementation of the WFD? The case of agricultural groundwater protection in northwest Germany. Local Environment 13:27-41

$\left.{ }^{21}\right]$ Frederickson, H. George. (1982). The Recovery of Civism in Public Administration. Public Administration Review, 42: 501-08

$\left.{ }^{22}\right]$ Nalbandian, J. (1999). Facilitating community, enabling democracy: New roles for local government managers. Public Administration Review, 59 (3), 187-197.

$\left.{ }^{23}\right]$ Gen, S., \& Wright, A. C. (2013). Policy Advocacy Organizations: A Framework Linking Theory and Practice. Journal of Policy Practice, 12(3), 165

$\left[{ }^{24}\right]$ Kastens, B., and J. Newig. 2008. Will participation foster the successful implementation of the WFD? The case of agricultural groundwater protection in northwest Germany. Local Environment, 13:27-41.

$\left.{ }^{25}\right]$ Frederickson, H. George. (1982). The Recovery of Civism in Public Administration. Public Administration Review, 42: 501-08

$\left.{ }^{26}\right]$ Nalbandian, J. (1999). Facilitating community, enabling democracy: New roles for local government managers. Public Administration Review, 59 (3), 187-197.

$\left[{ }^{27}\right]$ Sabatier, P.A., and Jenkins-Smith, H. (eds.) (1993). Policy change and learning: an advocacy coalition approach. Boulder, CO: Westview.

$\left[{ }^{28}\right]$ Sabatier, P. A., \& Jenkins-Smith, H. C. (1999). The advocacy coalition framework: An assessment. Boulder, CO: Westview Press, pp. 142.

$\left[{ }^{29}\right]$ Sabatier, Paul A. (1998). The advocacy coalition framework: revisions and relevance for Europe, Journal of European Public Policy, 5(1): 98-130

[30] Fyall, R., \& Mcguire, M. (2015). Advocating for Policy Change in Nonprofit Coalitions. Nonprofit and Voluntary Sector Quarterly, 44(6), 1274-1291.

[31] Kim, Y.-J., \& Roh, C.-Y. (2008). Beyond the Advocacy Coalition Framework in Policy Process. International Journal of Public Administration, 31(6), 668-689.

[32] Eaton, C., \& Weir, M. (2015). The Power of Coalitions: Advancing the Public in California's Public-Private Welfare State. Politics \& Society, 43(1), 3-32.

[33] Marina (1999:4) in Sørensen, G. (2008). Democracy and democratization: Processes and Prospects in A Changing World (Third Edit). Colorado: Westview Press, pp. 96.

[34] Islam, M. R., \& Morgan, W. J. (2012). Nongovernmental organizations in Bangladesh : their contribution to social capital development and community empowerment. Community Development Journal, 47(3), 376.

$\left.{ }^{35}\right]$ Nations, U. (2006). Public Administration and Democratic Governance: Governments Serving Citizens. In 7th Global Forum on Reinventing Government Building Trust in Government 2629 June 2007, Vienna, Austria. United States of America: United Nations Publication, pp. 206.

$\left[{ }^{36}\right]$ Petras, J., \& Veltmeyer, H. (2011). Social Movements in Latin America: Neoliberalism and Popular Resistance. New York: Palgrave Macmillan, pp. 1.

$\left[{ }^{37}\right]$ Gen, S., \& Wright, A. C. (2013). Policy Advocacy Organizations: A Framework Linking Theory and Practice. Journal of Policy Practice, 12(3), 165.

$\left[{ }^{38}\right]$ Kinchen, S. J. (2011). We want what people generally refer to as Black Power": Youth and student activism and the impact of the Black Power Movement in Memphis, Tennessee, 1965-1975. Disertation. The University of Memphis.

$\left.{ }^{39}\right]$ Contreras, R. (1993). The ideology of the political movement for Chicano studies. Disertation. University of Los Angeles.

$\left[{ }^{40}\right]$ Liebner, K. M. (2006). The Political Process Model: A Case Study of the Alaskan Native Land Rights Movement Thesis Presented to the McAnulty College and Graduate School of Liberal Arts Duquesne University in partial fulfillment of the requirements for the degree of Master of $A$. Duquesne University. 
$\left.{ }^{41}\right]$ Beziou, A. (1993). On Ethnic Political Mobilization; The Case Of The Berber Movement in Algeria. University of Denver.

$\left.{ }^{42}\right]$ Claybrook, M. K. (2016). Student Engagement , Cultural Politics, and the Black Students Movement: A Case Study in Los Angeles, 1965 1975. Claremont Graduate University.

$\left[{ }^{43}\right]$ Ko, R. S. (2008). Political Context and Collective Action: Student Movement Networks Alliance with the Middle-class in the Democratization of Korea. Disertation. The Catholic University of America.

$\left[{ }^{44}\right]$ Griffin, P., \& Thurber, J. A. (2015). Teaching public policy advocacy by combining academic knowledge and professional wisdom. Interest Groups \& Advocacy, 4(1), 40-51. 